\title{
継続的健診成績の蓄積と一次予防への適応について
}

一生涯健診デー夕の蓄積と互換性への提言一

菅沼 源二 ${ }^{11}$

抄録

平成 18 年 6 月, 第 164 通常国会において, 医療制 度改革関連法案等 8 法案が成立した。

これにより，平成 20 年 4 月より，40 歳から 74 歳 までの被扶養者を含むすべての被保険者は，特定健 診，特定保健指導を受診しなければならないことに なった。

対象疾患は生活習慣病の内，内臓脂肪症候群に限 定されている。

特定健診では, 肥満者, 特に内臓脂肪の蓄積が疑 われる対象者を抽出し，特定保健指導により，日常 の生活習慣の改善により，肥満の解消を図ることに より,メタボリックシンドロームを中心とする脳, 心臓疾患の発症やより重篤な方向への進行を回避し ようとするものである。

総合健診医学会では過去 30 有余年にわたり，健診 を実施する専門医学会としての業績を積んできた が，健診の実施による有所見者の選別には多くの業 績が見られるが, 有所見者を対象とした, 生活指導, 保健指導への介入，健康増進への改善指導に関する 実績は十分とはいえない状況である。

今回の特定保健指導では, 肥満者の $25 \%$ を削減す るという明確な数值目標が健診成果として求められ ている。

確実なアウトカムを求めるならば，受診者の「肥 満」および内臓脂肪症候群に対する, 自分自身の健 診結果に対する確実な理解と認識がなければならな い。

受診者が，満足する「健診結果の十分な説明」が 重要な第一歩と考える。

本発表は, 継続的な受診記録の一覧性を重視した 上で，受診者が自らの受診結果の理解を助けるため

1 ）特定非営利活動法人健康増進事業支援協会
のツールとして検討したものであり，すべてはコン ピュータによって支援されるものである。

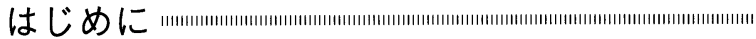

平成 18 年 6 月の第 164 通常国会において医療制度 改革関連 8 法案が通過，成立した。

これら関連法案の成立により, 法律第 83 号ならび に 84 号に基づいて, 平成 20 年 4 月より，40 歳から 74 歳までの被扶養家族を含む被保険者のすべてに ついて, 特定健診, 特定保健指導が義務付けられた。 生活習慣に起因する内臓脂肪症候群（メタボリッ ク症候群）を主目的として，特定健診において有病 者ならびにその予備群を抽出し，特定保健指導によ り，メタボリックシンドロームへの可能性を持つ肥 満者の $25 \%$ 以上を削減しようとするものが法律の 意図である。

目的

特定健診は，特定保健指導を必要とする対象者を 抽出することが主たる目的であり，特定保健指導 は, 対象者の生活習慣に介入して対象肥満者の $25 \%$ を改善するという数值目標を掲げている。

対象疾患は，メタボリックシンドロームに特定さ れており，対象疾患を発見するための健診項目も限 定されている。肥満については, BMI と腹囲による 肥満度の選別が基準とされている。

メタボリックシンドロームは，肥満を基礎疾患と して, 高血圧, 高脂血症質, 糖尿病の内, 1 ないし 2 以上の合併症を有するものの選別，抽出を目的と している。

したがって, 特定健診の検査項目は, 肥満度と腹 囲，高血圧については血圧，高脂血症に対しては， TG，HDL，LDLの 3 項目，糖尿病に対しては，空 
腹時血糖, $\mathrm{HbA1c}$ と尿糖が指定されたものである。

簡潔な選別基準であるが，肥満症を抽出した後に 血圧や, 血糖, 脂質の測定が行われるわけではなく, 特定健診として受診した場合には, 上記のスクリー ニング項目は同時に測定され, その測定結果の判定 により, 肥満症でなく, 瘦せていても高血圧, 高血 糖が指摘されることは当然であり, 肥満を中心とす る選別基準に対して心臓病や脳卒中では瘦せていて も危険性が高いことが指摘されているが，スクリー ニングレベルにおいて, 判定を行う医師により正し く選別され, 適切な特定保健指導が実施されるもの と考える。

ただし, 特定保健指導の適応を指摘された受診者 に, 当日の受診結果の説明を行い, 特定保健指導に 介入するまでに「十分納得の行く説明」を行うこと の重要性は, 十分理解はされているのであるが, 現 実には, 受診者の健康への関心度や理解度に差があ り, 当日の特定保健指導の時間（20 分）以内で, 受 診者に一律に生活習慣の改善への動機付けや積極的 な指導を効果的に実施できるかどうかは疑問であ り, 何らかの説明のための, 支援策が必要となるの ではないかと考える。

そこで, 健診成績の判定基準をもとに, 共通表示 法に従った成績の視覚化を検討し, 特定健診, 特定 保健指導に適応した要素を備えた, 継続成績の判定 表示法を検討したので報告する。

\section{方法ならびに結果 "}

上に示した特定健診項目を総合健診で実施されて いる共通表示法に従って, 成績の一覧表を検討した (表 1)。

特定健診項目に対する判定基準は厚生労働省の暫 定基準案に従ったので, 今後, 平成 20 年の実施まで には, 改正案が示され, 基準值の改正も行われるこ とと思われる。

改定の都度，基準值は入れ替えることにより，ス コア值はいつも同じ診断水準を保つことが可能であ り，施設間の基準值の差にも直ちに対応が可能であ る。

また，健診項目の増隇に対しても，コンピュー夕 のプログラムに対応させておけば, 追加, 削減など, 変更は容易に実施可能である。

表 1 により順次説明をする。

基準値の下限はスコア值の 80 に相当するもので,
スコア值 100 の中央値は保健指導を要する下限値と して厚生労働省が提示しているものである。

120 の上限値には受診勧奖判定值を充当した。

表示の色は，交通信号機の表示色を用い，スコア 值 80 から 100 までの健常値域の成績は安全を示す青 色とし，スコア值の 100 から 120 までは黄色の要指 導域として警戒を意味している。スコア 120 以上の 受診勧奨閾值では，危険を象徵する赤色とした（表 は白黒掲載)。

特定健診においては, 特定保健指導を必要とする 対象者を抽出するための検査項目であるが, 肥満症 の判定が優先するので, 最上段に肥満度を BMI とし て表示し，継続的な受診成績でどのような肥満の状 態を辿ったかが経緯を一目で判別できるようにし た。

実際の特定保健指導の場においては, 黄色のゾー ンに, 成績が出力されているものについてのみ, 指 導対象となるのであり, 青色ゾーン, 赤色ゾーンに 成績のあるものについては，情報提供のみ，または 要治療領域者として受診勧奨を行うことになり, 健 診成績の説明で終了することになる。

黄色ゾーンに成績のあるものについては，健診成 績の説明の段階から, 生活習慣に介入する心構えで 説明を実施することが大切である。

継続検查成績において蓄積した成績間の比較を可 能にするための重要なものの一つに，施設間の成績 の信頼性の度合いと測定単位や測定法による互換性 の確立が挙げられるが, 共通表示法ではもともと, 施設間で異なる基準値によって判定されている検查 成績を基準值を用いて共通に評価を可能にした手法 であることから, 今回の判定基準閾值が厚生労働省 によって提示された判定基準を用いており，共通の 基準物質による検査精度の校正により互換性は保証 されたものとするという原則に従った。

BMIのように, 全国で統一されているCGS (MKS) 単位によるものであっても, 施設間には測定 の誤差は存在する。そこで, 前回までの施設間の測 定值の比較に当たって, 測定誤差のあるものについ

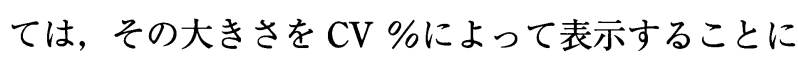
した。

特定保健指導の効果を一目で確認したいという要 請に対しては, 前回差を信号色に象徴される危険度 を潜在的に利用して隇少, 不変, 増加と表示した。

しかし, 継続的に受診して行く場合には, 服薬や サプリの効用により改善された成績を, 当日健診の 


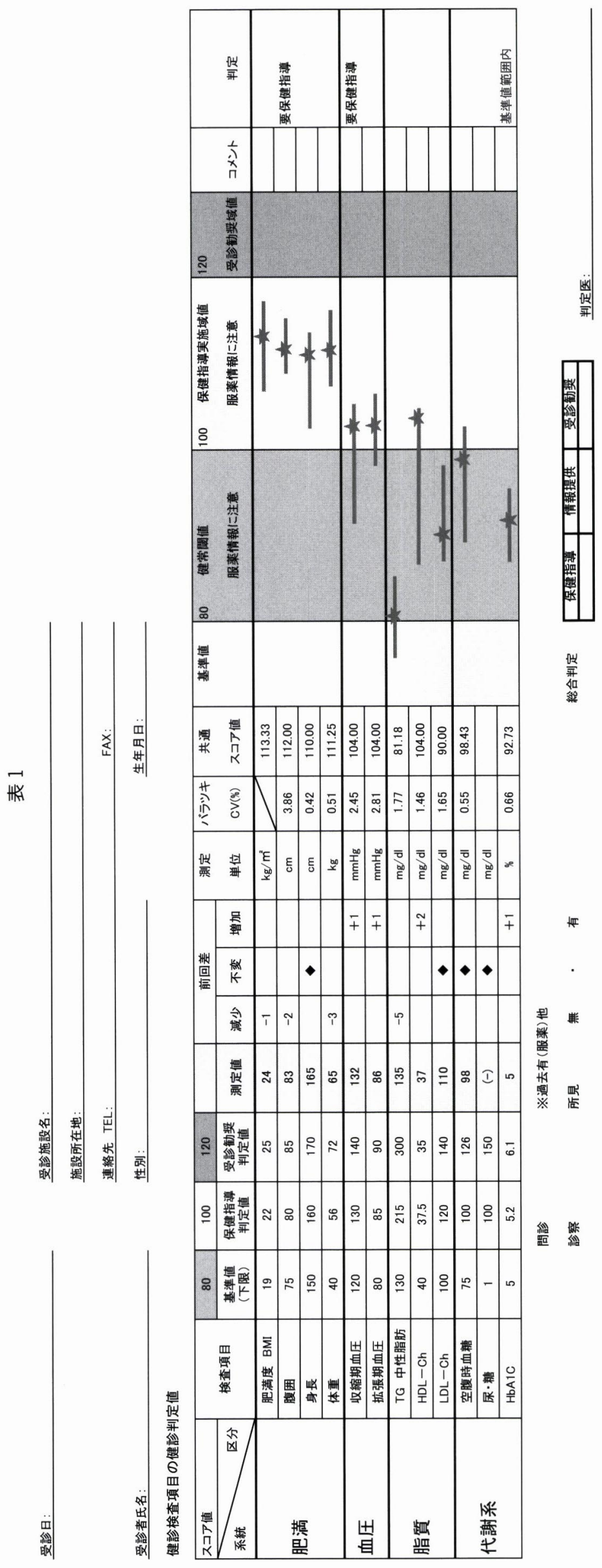




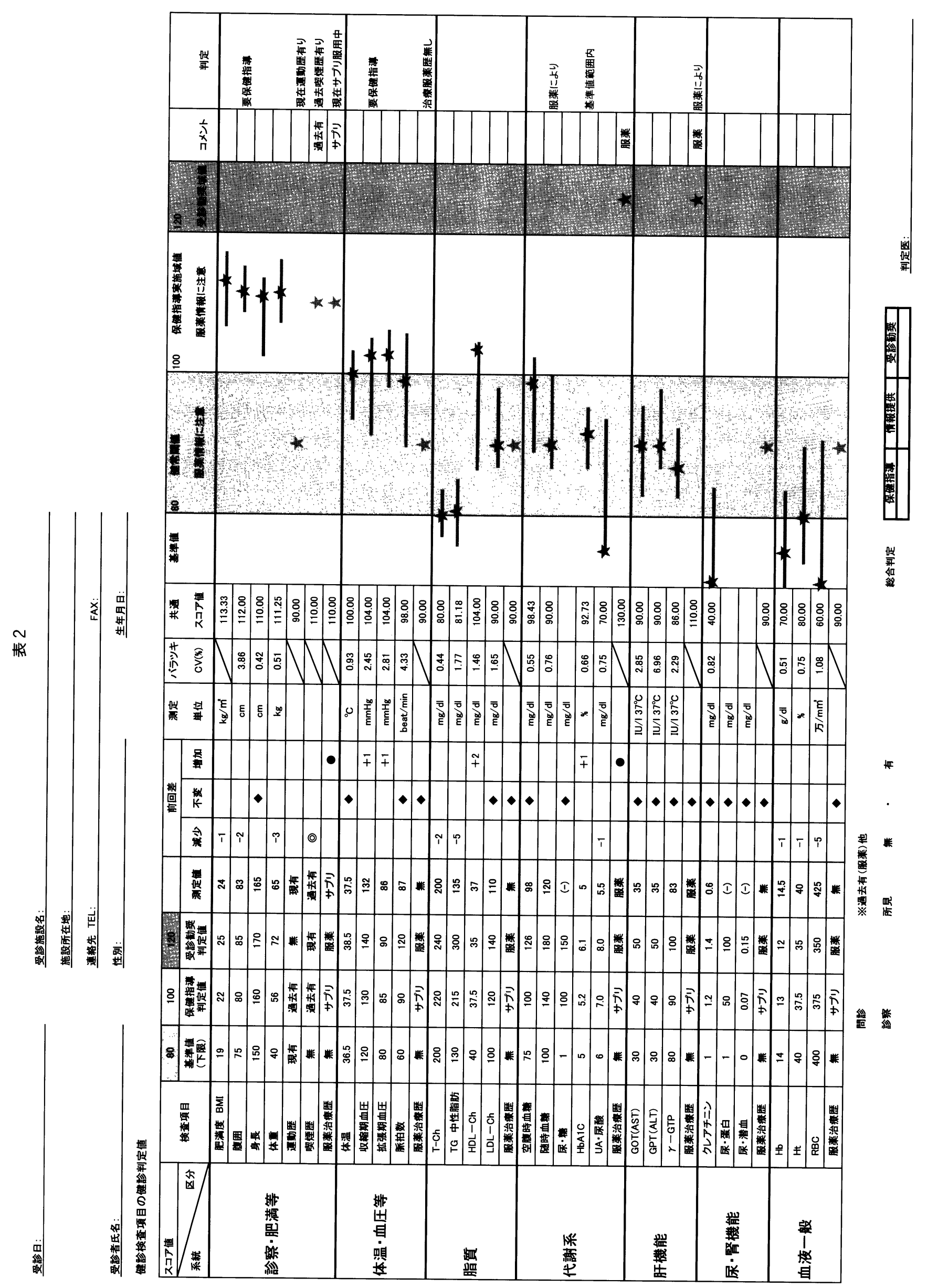


成績のみで判断することは，危険であるところか ら, 問診等で申告された服薬情報を共通表示に一元 化することを諮った。

全く服薬や喫煙の経験の無い場合は, 青色ゾー ン, 過去に服薬または喫煙の経験のあるもので現在 は中止中のものは，黄色ゾーン，現在服薬中のもの は赤色ゾーンに出力するようにし, 現況を選別して 表示する方法を行った。

スコア値の算定法は，基準值の中央値と当日の測 定值を比較し, その格差の大きさを基準值の $1 \mathrm{SD} に$ よって距離として表現したものをスコア值としてお り, 測定值の基準值による SDI 評価といえるもので ある。

今回の特定健診においては，基準値を健常域値の スコア值 80 とし, 保健指導実施閾值を 100 とし, 受 診勧奨域值を 120 とした。

したがって今回の中央值は保健指導域值であり， $\mathrm{SD}$ は基準值の下限值と受診勧奨域值の幅の 4 分の 1を $1 \mathrm{SD}$ とした。

結果の利用法としては, 多数の当日の受診者の中 から, 特定保健指導を必要とする対象者をいち早く 抽出する方法として活用する方法である。

当日の健診成績が黄色ゾーンにある人々は特定保 健指導の必要性が濃厚であることを前提として, そ れぞれの系統に属する服薬やサプリによる改善例で ないことの確認の後に, 受診者に特定保健指導への アプローチを開始することに用いることができる。

考察 継続して受診し，保健指導を行ってゆく段階で，
過度の節食などによる㙰血など，隠された二次的な 障害の見逃しを行わないために，厚生労働省の基準 検査項目以外に, 血液学的検査や肝・腎機能など, 総合健診で受診した受診者など成績のマージを検討 した（表 2)。

現実に他の目的で受診した検査成績をどのような システムによってマージして使用するか, 異なる次 元における問題の解決が必要になることを付言す る。

結 語

継続して受診する健診データを常に全体として把 握し, 検討の視野の中に置くための, データの一覧 の方法と必要な要素について検討した。

毎回の健診成績を入力さえすれば，既設の基準範 囲に従って, 直ちにスコアに変換し, 過去の成績と 同じ水準で, 比較評価が可能になるように設定し た。

将来，検査法の変更や基準範囲の変更が決定され た場合にも，基準值欄の数值を入れ替えることによ り計算式の変更なしに共通評価の基準となるスコア 值は算定されるようになっている。

この発表の機会をあたえて下さいました，日本総 合健診医学会理事, 第 35 回大会長の光宗先生に深謝 申し上げます。 